\title{
Economically optimal private land grazing strategies for the Blue Mountains of eastern Oregon
}

THOMAS M. QUIGLEY, JOHN A. TANAKA, H. REED SANDERSON, AND ARTHUR R. TIEDEMANN

\begin{abstract}
The Oregon Range Evaluation Project implemented 3 levels of grazing management intensities (strategies) on private land pastures in the Blue Mountains of northeastern Oregon. Prior to implementing each management strategy, a coordinated resource plan was prepared and a benefit-cost analysis on each practice and pasture was performed. The goal was to achieve the largest economic return from grazing for each strategy implemented. Returns above variable costs were used to select the optimal grazing strategy for the ecosystems represented. The commodity production strategy was found to be optimal in all ecosystems over a wide range of interest rates, management costs, and beef prices.
\end{abstract}

Key Words: economics, grazing management, commodity production

Land management decisions have been influenced by economic processes since the settlement of the West. Economic decisions in range management occur at the practice level, the pasture level, and the ranch or allotment level. Choices at the pasture level include selection of practices to be implemented (how many miles of fence to construct, how many acres to seed, and which water developments to install). At the ranch and allotment level, decisions are made with respect to the number and size of pastures and respond to national or regional policies, coordination with national programs, price supports, and establishment of fees. Ranches and allotments combined comprise the production system of a region or nation.

Broad policy decisions directly affect the economics of practice implementation. Economic decisions of investments are related to the economic well being of regions and nations. These types of economic decisions are interdependent. A recent review of the range economics literature shows many studies at the practice and

\footnotetext{
Authors are range scientist, Pacific Northwest Research Station, La Grande, Oregon 97850; assistant professor, Department of Agriculture and Resource Economics, Oregon State University Agriculture Program, Eastern Oregon State College, La Grande, Oregon 97850; and range scientist and principal range scientist, Pacific Northwest Research Station, La Grande, Oregon 97850.

Manuscript accepted 21 April 1990.
}

ranch level, but few at the pasture level (Wagstaff 1986). The objectives of this study were to determine costs and revenues of managing ecosystems at different intensities and to determine the most economic grazing strategies for ecosystems of the Blue Mountains in eastern Oregon on private lands.

\section{Study Area and Methods}

The Oregon Range and Related Resources Evaluation Area Project (EVAL) was started, in part, to determine the costs and benefits associated with different intensity levels of range management. The overall study has examined forage, water quantity and quality, storm runoff, and associated impacts of range management on resources (Sanderson et al. 1988). The EVAL area is about 485,000 hectares ( 1.2 million acres) of private and public land (the northern half of Grant County, Ore.). Private ranchers had to apply to be included in the EVAL study. Coordinated plans were developed for selected ranches. The planning process was led by the USDA Forest Service and included all Federal, State, and private lands associated with the selected ranches. Beginning in 1976 and ending in 1986, coordinated plans were developed and implemented for over 137,500 hectares $(340,000$ acres) of private and public rangelands in the Blue Mountains of eastern Oregon. Only private land management will be considered in this paper.

Range management strategies were planned and implemented on 140 pastures (21 ranches). Cost share arrangements were made to partially finance improvements on private land. All practices were monitored for compliance with standards specified by the EVAL team, an interagency group with leadership responsibilities for the EVAL project. Physical specifications were the same on all land ownerships and were developed with private landowners, agency planners, and the county committee for the Agricultural Stabilization and Conservation Service.

The coordinated resource planning process followed that outlined by Sanderson et al. (1988). An interdisciplinary team developed a management plan for all rangelands that included an 
assessment of the improvement potential for each pasture. A management intensity (grazing strategy) was selected for each pasture with guidance from the private landowner. Specific practices for the management strategy were selected and scheduled for implementation. Each individual practice was subjected to standard investment analysis (benefit-cost or net present value) prior to being included in the strategy. Practices were implemented between 1976 and 1981. Gathering and monitoring of data continued through September 1984.

$A$ benefit-cost approach was used in the analysis. Benefits were estimated as beef production and were converted to monetary values using an average price for beef. Costs were estimated for improvements, maintenance of improvements, and management of livestock. Benefits and costs were annualized (amortized) and the difference, net revenue, determined. The optimal strategies were defined to be those with the largest net revenue.

\section{Management Strategies}

Range management intensity within a pasture was defined by management strategies (Sanderson et al. 1988). Strategies (Table 1)

Table 1. Range management strategy definitions.

\begin{tabular}{cl}
\hline \hline Strategy & Definition \\
\hline A & Environmental management without livestock \\
B & Environmental management with livestock \\
& Goal-livestock control \\
& Typical management practice-fencing \\
C $\quad \begin{array}{l}\text { Extensive management of livestock and environment without } \\
\text { cultural practices } \\
\text { Goal-uniform livestock distribution } \\
\text { Typical management practices-fencing, water developments, } \\
\text { access trails } \\
\text { Intensive management of livestock and environment with } \\
\text { cultural practices } \\
\text { Goal-enhancing forage production and uniform livestock } \\
\text { distribution } \\
\text { Typical management practices-fencing, water developments, } \\
\text { access trails, thinning, seeding, fertilization, brush control, } \\
\text { irrigation } \\
\text { Maximize commodity production with no degradation of base } \\
\text { resources and no constraining multiple use consideration on } \\
\text { private land } \\
\text { Goal-enhancing commodity production and uniform live- } \\
\text { stock distribution } \\
\text { Typical management practices-fencing, water developments, } \\
\text { access trails, thinning, seeding, fertilization, brush control, } \\
\text { irrigation }\end{array}$ \\
\end{tabular}

were defined to provide a practical management perspective. Management intensity progresses from excluding livestock (strategy $A$ ) to commodity production with no environmental constraints (strategy E). Practices compatible with a strategy at a lower level are also consistent with higher level strategies; however, some practices at a higher level may not be consistent with strategies at lower levels.

The objective of strategy implementation was to achieve the largest economic returns possible. Expected costs and expected benefits were considered before implementation of practices, rather than implementing large-scale practices and analyzing the costs and benefits after implementation. Decisions were based on the expected increase in net revenues of the projects to be implemented. This objective differs from other studies of range improvement (for example, Heady and Bartlome 1977, Pope and Wagstaff 1987) where both low and high productive areas were treated and included in the analysis. If a large proportion of the area were in low productive status, there would be a bias in the analysis toward a poor benefit-cost ratio. Areas where forage could have been increased through treatment were generally excluded from treatment in this study when costs exceeded benefits. Exceptions included treatments where all benefits could not be quantified in economic terms yet were important to the EVAL team and manager or owner. At all strategy levels, basic soil and water resource values were protected.

\section{Cost Determination}

Cost accounting procedures were implemented to track the resources used to install the range practices. This included labor, equipment, and materials; for example, miles driven, hours and type of equipment used, number of fence posts, rolls of barbed wire, amount of seed applied, and so on for all resources. These were converted into dollar amounts in 1978 costs (FOB John Day, Ore.). Cost information was separated by skilled labor, unskilled labor, equipment, and material expenses for each practice type (Quigley et al. 1989, Quigley and Sanderson 1989). More than 800 individual practices were monitored.

\section{Direct and Fixed Costs}

All direct costs of implementation and maintenance of the practices were assessed to the grazing strategy. When costs were incurred for purposes other than grazing, the separable costsremaining benefit approach (Gittinger 1982) was used to assign only those costs of the practices that provided range benefits to the grazing strategy. An additional cost allocation process was necessary to provide costs on an ecosystem basis because most pastures included more than 1 ecosystem. Benefits from a practice occurring in only 1 ecosystem may spread to the entire pasture. For example, a pasture with 3 ecosystems each having one-third of the area could have only 1 water development in the pasture. The cost associated with constructing, maintaining, and managing the single development was allocated proportionally to all 3 ecosystems contributing to grazing capacity. We totaled all grazing costs in a pasture and proportionally allocated them to the ecosystems in the pasture based on their contribution to the total grazing capacity of the pasture.

Fixed costs were neither measured nor estimated in this study. Fixed costs are those that do not vary with changing levels of production; they are important in the decision to produce or not to produce but not in the level of production (Workman 1986). It was assumed in the analysis that the physical plant (e.g., land area, facilities) was constant over the life of the analysis. Research in North Dakota shows that implementation of short-duration graz-

Table 2. Numbers of ecosystem and pasture combinations by strategy.

\begin{tabular}{lr}
\hline \hline Total number of pastures & 139 \\
Number of pastures with & \\
Strategy C & 37 \\
Strategy D & 27 \\
Strategy E & 75 \\
Number of pastures with ecosystem & \\
Douglas-fir & 17 \\
Ponderosa pine & 39 \\
Larch 1 & 6 \\
Sagebrush & 51 \\
Juniper & 56 \\
Mountain grassland & 88 \\
Mountain meadow & 28 \\
Total number of ecosystem-pasture cells & 285 \\
\hline
\end{tabular}

'Excluded from analysis. Not enough observations across strategies. 39 
ing systems on ranches increases fixed costs an average of $5 \%$ (Mack 1985). Implementing EVAL strategies involved fewer improvements than typically occur with short-duration grazing systems and would likely result in a small increase in fixed costs. Therefore, the potential bias associated with excluding fixed costs should have little effect on the economically optimal strategies of the EVAL program.

\section{Management Costs}

Costs for livestock management were estimated on an AUM basis following the Oregon data reported by Obermiller and Lambert (1984). The costs included expenses for turn-out, round-up, movement, routine management, salting, feeding, veterinary services, meetings, death loss, fees, and rent. Multiplying the costs per AUM by the number of AUM's in a given ecosystem resulted in an estimate of the cost of livestock management for the ecosystems within the pasture.

\section{Annualized Costs}

All costs were adjusted to 1978 dollars by using the prices-paid index (USDA Statistical Reporting Service 1987). Costs were annualized over a 50-year planning horizon at interest rates of 4,7 , and $10 \%$ to determine the annual amount of money required to implement and maintain the given management strategy for $\mathbf{5 0}$ years and pay interest at the selected rate. All developments and improvements were assumed to have a useful life of 25 years. Each practice was considered as replaced once during the planning period. At year 25, we assumed the maintenance costs exceeded the costs of replacement and had therefore reached the end of its economic life. The selected interest rates represented estimates of the long-term real cost of capital (opportunity cost plus risk, but without inflation).

\section{Benefit Determination}

Although management of rangelands can result in many market and nonmarket benefits, we chose to consider only marketable beef benefits for this analysis. Practices implemented through EVAL had more than a single purpose with benefits accruing to other resources such as wildlife, soil, and water. Although these were important considerations in implementing practices, the selection of grazing strategies at the pasture level was made on the basis of marketable beef. The procedure required estimates of grazing capacity (AUM's) and marketable beef by ecosystems within pastures.

\section{AUM Allocation}

AUM allocation refers to the process of allocating the total estimated AUM capacity in a pasture to the ecosystems within that pasture. Records of actual use were obtained and forage utilization maps drawn for each pasture in the study at the end of each grazing season. The Soil Conservation Service personnel were responsible for gathering and interpreting this information. The SCS made recommendations on next year's stocking rate and the management plan was based, in part, on this information.

The AUM allocation process used ecosystem and forage utilization maps, actual-use records, personal knowledge of practices and management, and the personal experience of the team members. The total number of AUM's for each pasture was estimated and then allocated to the ecosystems represented in the pasture.

\section{Beef Production}

Beef production was simulated for yearling heifers following McInnis et al. (1986). Data related to the production of beef from ecosystems in the Blue Mountains were available for yearling heifers but not for steers (Holechek 1980). Comparisons across strategies and pastures using heifer data provided consistent results even though few ranchers run all heifers in a given pasture and heifer gains will generally be lower than steer gains. The simulation model considered the amount of forage available for consumption in each ecosystem within a pasture and adjusted it for distance to water and slope in each of 5 periods of grazing during the year. Forage requirements were determined for the heifers and compared to the adjusted available forage in each season. Results of the model were pounds of beef production per acre by ecosystem within pastures. The simulation model was used predictively to convert the number of AUM's of grazing allocated to each ecosystem within a pasture to beef production. The model was forced to equate AUM production with the AUM's allocated.

Monetary benefits of beef production were taken as the value of the product derived from the use of forage on private lands by domestic livestock. Estimates were made of the amount of beef produced on each ecosystem area within a pasture and were multiplied by the adjusted average price of beef for the United States. Beef prices were taken as the 1977-1985 average received for steer and heifer beef in the United States (USDA 1986) and adjusted to the 1978 base year ( $\$ 54.32$ per hundred weight). The analysis used the average price, a $25 \%$ higher value, and a $25 \%$ lower value to test the sensitivity of optimal strategies.

\section{Optimal Strategies}

Optimal strategies were determined for each ecosystem by determining the greatest return above variable cost. Averages were

Table 3. Stocking rate in hectares per AUM as determined through the AUM allocation process.

\begin{tabular}{|c|c|c|c|c|c|c|c|}
\hline \multirow[b]{2}{*}{ Strategies } & \multicolumn{7}{|c|}{ Ecosystem } \\
\hline & $\begin{array}{l}\text { Douglas- } \\
\text { Fir }\end{array}$ & $\begin{array}{l}\text { Ponderosa } \\
\text { Pine }\end{array}$ & Sage & Juniper & $\begin{array}{l}\text { Mountain } \\
\text { Grassland }\end{array}$ & $\begin{array}{c}\text { Mountain } \\
\text { Meadow }\end{array}$ & $\begin{array}{r}\text { Overall } \\
\text { Average }\end{array}$ \\
\hline \multicolumn{8}{|l|}{ Strategy C } \\
\hline Ave' 1 & 1.55 & 1.53 & 1.84 & 2.32 & 2.07 & 0.43 & 1.83 \\
\hline SE & 0.33 & 0.18 & 0.25 & 0.18 & 0.29 & 0.08 & 0.14 \\
\hline $\mathbf{n}$ & 4 & 8 & 11 & 12 & 26 & 6 & 67 \\
\hline \multicolumn{8}{|l|}{ Strategy D } \\
\hline Ave & 1.66 & 1.25 & 1.43 & 2.22 & 1.82 & 0.54 & 1.63 \\
\hline SE & 0.55 & 0.13 & 0.24 & 0.23 & 0.23 & 0.19 & 0.11 \\
\hline $\mathrm{n}$ & 4 & 13 & 13 & 19 & 16 & 6 & 71 \\
\hline \multicolumn{8}{|l|}{ Strategy E } \\
\hline Ave & 1.37 & 1.54 & 1.31 & 1.93 & 1.22 & 0.30 & 1.31 \\
\hline $\mathrm{SE}$ & 0.30 & 0.19 & 0.23 & 0.19 & 0.15 & 0.06 & 0.09 \\
\hline $\mathbf{n}$ & 9 & 18 & 27 & 25 & 46 & 16 & 141 \\
\hline
\end{tabular}

'Ave = average; $\mathrm{SE}=$ standard error of mean; $n=$ sample size. 
taken across pastures at the same strategy level. Variable costs were taken as the sum of the annualized costs for improvements, improvement maintenance, and management costs. Fixed costs were excluded from the analysis. Optimal strategies were determined for 27 different combinations of interest rates ( 3 rates), beef prices ( 3 levels), and management costs ( 3 levels). Stocking rates, costs, benefits, and net revenues were analyzed using analysis of variance procedures to determine differences among ecosystems and strategies.

\section{Results and Discussion}

Management strategies implemented through EVAL were successful in providing increased grazing capacity (Quigley et al. 1986). During EVAL, strategies were implemented and monitored on 139 pastures (Table 2). Within these pastures Douglas-fir (Pseudotsuga menziesii), ponderosa pine (Pinus ponderosa), western larch (Larix occidentalis), sagebrush (Artemisia spp.), juniper (Juniperus spp.), mountain grassland, and mountain meadow ecosystems were represented as characterized by Garrison et al. (1977). Sufficient data for analysis existed only for extensive, intensive, and commodity production $(C, D$, and $E$ ) strategies on private land. The western larch ecosystem was excluded from the analyses due to insufficient data across all strategy levels. The optimal strategies described here are optimal above the environmental management (B) level.

\section{Stocking Rates}

The anticipated pattern of less land required per AUM as management intensity increased was generally observed. Stocking rates were greater with strategy $\mathbf{E}$ (commodity production) level than with strategy $C$ (extensive) on all ecosystems except for the ponderosa pine ecosystem, which were similar (1.53 hectares/AUM vs. 1.54 hectares/AUM) (Table 3). Private land pastures were generally small and tended to have uniform treatment on all ecosystems within a pasture. For example, when strategy E was implemented on a pasture with Douglas-fir, mountain meadow, and juniper, improvements included all 3 ecosystems with such practices as thinning, juniper control, and seeding. Thus, increased capacities were generally noted in all ecosystems within pastures at the $E$ level. At strategy D (intensive), the implementation of cultural treatments may not have involved all ecosystems within a pasture but the entire pasture was included in the management strategy. Use may then shift away from other ecosystems within that pasture resulting in a relative reduction in capacity on those ecosystems. This different treatment is likely the reason for the decreased capacity between strategies $C$ and $D$ on Douglas-fir and mountain

Table 4. Costs, benefits, and net returns above variable costs (1978 dollars per hectare) on private land with interest rate at 7\%, beef price at $\$ 54.32$ per hundred weight, and management costs at $\$ 3.67$ per AUM.

\begin{tabular}{|c|c|c|c|c|c|c|c|}
\hline \multirow[b]{2}{*}{ Strategies } & \multicolumn{7}{|c|}{ Ecosystem } \\
\hline & $\begin{array}{l}\text { Douglas- } \\
\text { Fir }\end{array}$ & $\begin{array}{l}\text { Ponderosa } \\
\text { Pine }\end{array}$ & Sage & Juniper & $\begin{array}{l}\text { Mountain } \\
\text { Grassland }\end{array}$ & $\begin{array}{l}\text { Mountain } \\
\text { Meadow }\end{array}$ & $\begin{array}{l}\text { Overall } \\
\text { Average }\end{array}$ \\
\hline $\begin{array}{l}\text { Strategy C } \\
\text { Sample size }\end{array}$ & 4 & 8 & 11 & 12 & 26 & 6 & 67 \\
\hline $\begin{array}{l}\text { Costs } \\
\text { Ave }^{1} \\
\text { SE }\end{array}$ & $\begin{array}{l}7.93 \\
1.83\end{array}$ & $\begin{array}{l}7.61 \\
0.86\end{array}$ & $\begin{array}{l}6.82 \\
1.06\end{array}$ & $\begin{array}{l}7.46 \\
2.08\end{array}$ & $\begin{array}{l}6.20 \\
0.40\end{array}$ & $\begin{array}{r}23.45 \\
5.19\end{array}$ & $\begin{array}{l}8.35 \\
0.86\end{array}$ \\
\hline $\begin{array}{l}\text { Benefits } \\
\text { Ave } \\
\text { SE }\end{array}$ & $\begin{array}{r}23.45 \\
3.26\end{array}$ & $\begin{array}{r}28.66 \\
3.04\end{array}$ & $\begin{array}{r}25.62 \\
6.89\end{array}$ & $\begin{array}{r}16.65 \\
1.31\end{array}$ & $\begin{array}{r}25.25 \\
2.57\end{array}$ & $\begin{array}{r}107.46 \\
20.44\end{array}$ & $\begin{array}{r}31.43 \\
3.73\end{array}$ \\
\hline $\begin{array}{l}\text { Net Returns } \\
\text { Ave } \\
\text { SE }\end{array}$ & $\begin{array}{r}15.49 \\
2.03\end{array}$ & $\begin{array}{r}21.05 \\
2.32\end{array}$ & $\begin{array}{r}18.80 \\
5.93\end{array}$ & $\begin{array}{l}9.22 \\
2.20\end{array}$ & $\begin{array}{r}19.03 \\
2.32\end{array}$ & $\begin{array}{l}84.01 \\
15.81\end{array}$ & $\begin{array}{r}23.08 \\
3.06\end{array}$ \\
\hline $\begin{array}{l}\text { Strategy D } \\
\text { Sample size }\end{array}$ & 4 & 13 & 13 & 19 & 16 & 6 & 71 \\
\hline $\begin{array}{l}\text { Costs } \\
\text { Ave } \\
\text { SE }\end{array}$ & $\begin{array}{l}6.62 \\
1.48\end{array}$ & $\begin{array}{r}12.43 \\
2.18\end{array}$ & $\begin{array}{r}11.64 \\
1.68\end{array}$ & $\begin{array}{l}8.55 \\
1.01\end{array}$ & $\begin{array}{l}9.91 \\
1.85\end{array}$ & $\begin{array}{l}43.37 \\
21.82\end{array}$ & $\begin{array}{r}12.97 \\
2.15\end{array}$ \\
\hline $\begin{array}{l}\text { Benefits } \\
\text { Ave } \\
\text { SE }\end{array}$ & $\begin{array}{r}27.06 \\
8.45\end{array}$ & $\begin{array}{r}36.25 \\
3.90\end{array}$ & $\begin{array}{r}35.93 \\
6.42\end{array}$ & $\begin{array}{r}19.37 \\
2.52\end{array}$ & $\begin{array}{r}26.46 \\
5.51\end{array}$ & $\begin{array}{r}108.97 \\
36.42\end{array}$ & $\begin{array}{r}35.09 \\
4.45\end{array}$ \\
\hline $\begin{array}{l}\text { Net Returns } \\
\text { Ave } \\
\text { SE }\end{array}$ & $\begin{array}{r}20.46 \\
7.17\end{array}$ & $\begin{array}{r}23.82 \\
3.85\end{array}$ & $\begin{array}{r}24.29 \\
5.07\end{array}$ & $\begin{array}{r}10.85 \\
2.40\end{array}$ & $\begin{array}{r}16.56 \\
4.57\end{array}$ & $\begin{array}{l}65.61 \\
17.94\end{array}$ & $\begin{array}{r}22.14 \\
2.77\end{array}$ \\
\hline $\begin{array}{l}\text { Strategy E } \\
\text { Sample size }\end{array}$ & 9 & 18 & 27 & 25 & 46 & 16 & 141 \\
\hline $\begin{array}{l}\text { Costs } \\
\text { Ave } \\
\text { SE }\end{array}$ & $\begin{array}{r}16.63 \\
4.89\end{array}$ & $\begin{array}{r}11.51 \\
2.22\end{array}$ & $\begin{array}{r}18.88 \\
2.57\end{array}$ & $\begin{array}{r}11.81 \\
2.40\end{array}$ & $\begin{array}{r}17.15 \\
2.17\end{array}$ & $\begin{array}{r}43.34 \\
4.82\end{array}$ & $\begin{array}{r}18.75 \\
1.41\end{array}$ \\
\hline $\begin{array}{l}\text { Benefits } \\
\text { Ave } \\
\text { SE }\end{array}$ & $\begin{array}{l}48.60 \\
14.04\end{array}$ & $\begin{array}{r}37.24 \\
7.44\end{array}$ & $\begin{array}{r}52.78 \\
8.23\end{array}$ & $\begin{array}{r}29.87 \\
6.20\end{array}$ & $\begin{array}{r}57.70 \\
8.23\end{array}$ & $\begin{array}{r}166.13 \\
21.74\end{array}$ & $\begin{array}{r}60.93 \\
5.39\end{array}$ \\
\hline $\begin{array}{l}\text { Net Returns } \\
\text { Ave } \\
\text { SE }\end{array}$ & $\begin{array}{r}31.97 \\
9.22\end{array}$ & $\begin{array}{r}25.72 \\
5.39\end{array}$ & $\begin{array}{r}33.90 \\
6.23\end{array}$ & $\begin{array}{r}18.06 \\
4.05\end{array}$ & $\begin{array}{r}40.55 \\
6.38\end{array}$ & $\begin{array}{r}122.76 \\
17.69\end{array}$ & $\begin{array}{r}42.18 \\
4.13\end{array}$ \\
\hline
\end{tabular}

IAve = average; $\mathrm{SE}=$ standard error of the mean. 
meadow ecosystems. Analysis of variance showed significant differences in stocking rates among ecosystems $(p<0.01)$ and significant interaction between ecosystem and strategy $(p<0.01)$.

\section{Costs}

All costs in a pasture were allocated to the ecosystems in the pasture based on the percentage of AUM's of grazing capacity that ecosystem contributed to the total. Improvement costs were taken from data gathered through the implementation phase of the EVAL project (Quigley et al. 1989). Management costs were determined on an AUM basis following Obermiller and Lambert (1984) and deflated to 1978. Management costs in 1978 dollars were \$3.67/AUM.

Costs by strategy and ecosystem at the intermediate interest rate (7\%) and management cost (\$3.67/AUM) were calculated (Table 4). Costs were expected to be greater for higher strategy levels. Costs for strategy $\mathbf{E}$ were greater than those for strategy $\mathbf{C}$ for all ecosystems. Strategy D cost less than strategy C in the Douglas-fir ecosystem, and strategy $E$ was less than the strategy $D$ in the ponderosa pine ecosystem. These apparent inconsistencies relate to the relative shifts in capacity observed within pastures. If practices in a pasture resulted in a higher strategy but shifted the proportion of capacity away from 1 ecosystem to another, the share of costs allocated to the ecosystem with fewer relative AUM's decreased even though the strategy was more intense. Analysis of variance showed significant differences in costs among ecosystems $(P<0.01)$ and significant differences among strategies $(P<0.01)$.

\section{Benefits}

The AUM allocation process estimated the grazing capacity for each ecosystem in a pasture. Data from each pasture were run through the beef simulation model to estimate pounds of beef produced within each ecosystem in each pasture (McInnis et al. 1986). All ecosystems showed increased benefits as the strategy changed from $C$ to $D$ to $E$ (Table 4). Juniper consistently had the lowest benefits per acre while mountain meadow consistently had the highest. Analysis of variance showed significant differences among ecosystems $(p<0.01)$ and among strategies $(p<0.01)$.

\section{Optimal Strategies on Private Land}

When beef prices, interest rates, and management costs were set at the medium level, the average net revenue for strategies $C, D$, and E were $\$ 23.08, \$ 22.12$, and $\$ 42.18$ per hectare, respectively, across all ecosystems. Strategy $\mathbf{E}$ was significantly greater than $\mathbf{C}$ and D $(p<0.01)$. Strategy $E$ was optimal on all ecosystems (Table 4).

Varying price, management cost, and interest rates resulted in no changes in optimal strategies. Thus, across the price and cost levels studied, strategy E remained optimal on all ecosystems. This strategy reflects the most intensively managed level we studied. Net revenues from this level of management appear to be the greatest over a wide range of prices and interest rates.

The mountain meadow ecosystem had the greatest net revenue per hectare with the net revenue for strategy $C$ exceeding that for strategy $D$. The juniper ecosystem had the lowest net revenue per hectare at each strategy level. There was nearly a seven-fold difference between juniper and mountain meadow net revenue per hectare (\$18.06 vs. \$122.79) at strategy E. A general conclusion from this analysis is that intensive management of private land will lead to the greatest net return over variable costs. The analysis did not consider fixed costs. The net returns over variable costs were positive for all strategy levels and all ecosystems studied. This indicates that the grazing strategy would be economically feasible, at least in the short-run. The net return over variable costs is available to pay for these fixed costs. It was not possible in this study to determine whether any of the management strategies would be feasible in the long run when all costs of production are considered.

\section{Conclusions}

For marketable beef, the economically optimal strategy for managing private land is for commodity production (strategy $\mathrm{E}$ ). This level of management was optimal over a wide range of interest rates, management costs, and beef prices. Range management strategies as applied in the EVAL study were comprised of a mix of practices that had been individually subjected to a benefit-cost analysis. Each strategy was applied to achieve the highest return over variable costs at the given strategy level. These costs and benefits represent average precipitation years; years of below- or above-average precipitation may show different optimal strategies. Fixed costs were not included in this analysis. Practices were implemented only on those sites where the potential production was sufficient to cover the cost or to achieve a goal of management, such as early forage for spring turnout. In many instances juniper and sagebrush treatments were applied to abandoned cropland sites invaded by these species. These productive sites responded well to treatments and resulted in positive net benefits. Results indicated that intensively managed pastures, with practices selected using benefit-cost criteria, will result in greater returns above variable cost than less intensively managed pastures.

\section{Literature Cited}

Garrison, G.A., A.J. Bjugstad, D.A. Duncan, M.E. Lewis, and D.R. Smith. 1977. Vegetation and environmental features of forest and range ecosystems. USDA Agr. Handbk. 475.

Gittinger, J.P. 1982. Economic analysis of agricultural projects, 2nd ed. Johns Hopkins Univ. Press, Baltimore.

Heady, H.F., and J. Bartolome. 1977. The Vale rangeland rehabilitation program: the desert repaired in southeastern Oregon. Pac. Northwest Forest and Range Exp. Sta. Resour. Bull. PNW-70.

Holechek, J.L. 1980. The effects of vegetation type and grazing system on the performance, diet, and intake of yearling cattle. Ph.D. Diss., Oregon State Univ., Corvallis.

Mack, L.E. 1985. Annual report: economic analyses of alternative ranch management practices. Current Research Information System (CRIS) 1985 Annu. Rep., North Dakota State Univ., Fargo.

McInnis, M.L., T.M. Quigley, and M. Vavra. 1986. Using computer simulation to estimate grazing capacity and beef production, p. 25-31. In: 1986 progress report... Research in rangeland management. Special Rep. 773. Oregon State Univ. Agr. Exp. Sta., Corvallis.

Obermiller, F.W., and D.K. Lambert. 1984. Costs incurred by permittees in grazing livestock on public lands in various western states. Oregon State Univ. Ext. Serv. EM 8283.

Pope, A.C., and J.F. Wagstaff. 1987. An economic evaluation of the Oak Creek range management area, Utah. Int. Forest and Range Exp. Sta. Gen. Tech. Rep. INT-224.

Quigley, T.M., K. Gibbs, and H.R. Sanderson. 1986. Rancher response to changes in Federal permitted livestock numbers in eastern Oregon. Rangelands 8:276-278.

Quigley, T.M., H.R. Sanderson, and A.R. Tiedemann. 1989. Managing interior northwest rangelands: the Oregon Range Evaluation Project. Pac. Northwest Res. Sta. Gen. Tech. Rep. PNW-GTR-238.

Quigley, T.M., and H.R. Sanderson. 1989. Analysis of fence construction costs. Rangelands 11:183-186.

Sanderson, H.R., T.M. Quigley, and L.R. Spink. 1988. Development and implementation of the Oregon Range Evaluation Project. Rangelands 10:17-23.

USDA. 1986. Agricultural prices: 1985 summary. USDA, National Agricultural Statistics Service, Agricultural Statistics Board, Washington, D.C.

USDA Statistical Reporting Service. 1987. Agricultural prices: 1986 annual summary. Crop Reporting Board, Washington, D.C., June 1987. PR 1-3(87).

Wagstaff, F.J. 1986. Range and ranch economics bibliography: 1968-85. Int. Forest Res. Sta. Gen. Tech. Rep. INT-216.

Workman, J.P. 1986. Range economics. MacMillan Publ. Co., New York. 